\title{
Los mecanismos de la interpretación: la eficacia de la ficción en la reconstrucción de la memoria a propósito de Los girasoles ciegos
}

\author{
The mechanisms of interpretation: \\ the effectiveness of fiction in the reconstruction \\ of memory about Los girasoles ciegos ${ }^{1}$
}

\author{
María de la Paz Cepedello Moreno \\ Universidad de Córdoba \\ Departamento de Ciencias del Lenguaje \\ fe2cemom@uco.es
}

\begin{abstract}
The aim of this paper is to demonstrate the important role that fiction can play in the reconstruction of historical memory. We start from some concepts proposed by phenomenology, and those wisely used by the literary pragmatics and aesthetics of reception, in order to explain the effect that fiction has on the reader regardless of contents or themes. The choice of Los girasoles ciegos is to illustrate the effectiveness of fictional stories in the reconstruction of historical memory through the use of four stories present suitable formal features. These stories allow the reader to interpret the text as own experience.
\end{abstract}

Keywords: fiction, aesthetics of reception, interpretation, historical memory, Los girasoles ciegos

\section{MEMORIA, FICCIÓN, LITERATURA}

Los múltiples éxitos que cosechó la singular y única obra de Alberto Méndez, los más importantes premios que se pueden otorgar a un texto narrativo en lengua española o la unanimidad de público y crítica en calificar Los girasoles ciegos como

\footnotetext{
${ }^{1}$ Este trabajo se inscribe en el proyecto Actualidad de la hermenéutica. Nuevas tendencias $y$ autores (FFI21013-41662-9).
} 
una pieza magistral, parecen estar en relación inversamente proporcional con el contenido de las historias que el escritor reconstruyó durante años y el desdichado y prematuro final del mismo. La derrota sin consuelo, tal y como titulaba el profesor Justo Serna (2005) a un interesante recorrido por el texto de Méndez cuando se cumplía prácticamente un año de su muerte. Y es que de todas las elogiosas, y a veces untosas, reseñas de las que ha disfrutado la obra que nos ocupa se me antoja que esta recoge una de las emociones que con más fuerza experimenta el lector, elemento clave de este estudio, de estas cuatro historias entrelazadas, el desconsuelo.

El recorrido fulgurante de Los girasoles ciegos desde su aparición, en enero de 2004, hasta la fecha, con más de veinticinco ediciones vendidas, se debe, en buena medida, no solo a su incuestionable calidad literaria sino, más específicamente, a su capacidad para producir en el receptor una desoladora "vivencia" que siente como propia. Desde este presupuesto de partida es posible y plausible hablar de la obra de ficción como un valioso instrumento para la reconstrucción de la memoria, más allá de la utilización de materiales tomados de fuentes documentales, testimonios fidedignos o de la experiencia vital. Alberto Méndez declara abiertamente sus intenciones cuando presenta el libro en el Círculo de Bellas Artes de Madrid: "el libro pretende ser, también, un homenaje a la memoria de nuestros padres [...] escrito con el olor y el ruido de la memoria de otros" (Garzón, 2004). Pero este objetivo no se hubiera cumplido plenamente de no ser, como nos enseña la estética de la recepción, por la intervención del lector, si entendemos la literatura como un proceso de comunicación especial que no se encuentra plenamente realizado hasta que la obra no es recepcionada y decodificada "adecuadamente".

La difusión de textos autobiográficos, de distinta naturaleza, que daban cuenta de la experiencia vital del horror, había comenzado "oficialmente" con los tímidos testimonios de algunos lúcidos supervivientes a la mortífera maquinaria nazi puesta en funcionamiento en unos cuantos nombres - Auschwitz, Mathausen, Buchenwald, Chelmno, Treblinka, Jasenovac, etc.-, que forma parte de la memoria colectiva de Europa. Buena parte de estos textos, como el nunca suficientemente elogiado Se questo è un uomo (1947) de Primo Levi, L'Espèce humaine (1947) de Robert Antelme o La nuit (1958) de Elie Wiesel, tardaron algunos años en adquirir el reconocimiento histórico y/o literario del que, con toda justicia, gozan hoy día porque, probablemente, tras haber vivido el más terrible episodio de la historia del siglo XX de nuestro continente, aún no se estaba preparado para leerlo. La contienda española y su desenlace no escapó, como cabría esperar, a su abordaje textual por parte de los que vivieron aquellos años fratricidas y tuvieron que elegir el exilio para no morir, que es lo mismo que no callar. Vale la pena recordar, como hace Eva Soler Sasera (2006), entre estos textos, Vida en claro (1944) de José Moreno Villa, Recuerdos y olvidos (1988) de Francisco Ayala, Memoria de la melancolía (1970) de María Teresa León o Memorias habladas, memorias armadas (1990) de Concha Méndez. Pero estos testimonios, con ser valiosos, no podían recoger, por razones obvias, 
la experiencia vital de los que sufrieron en carne propia el férreo aparato de represión contra los vencidos que el franquismo instauró tras el fin de la contienda. Sus voces, en el mejor de los casos, quedaron silenciadas con lo que una parte de la memoria histórica del siglo XX español estaba condenada a desaparecer.

Contemplado en perspectiva parece lógica la tendencia de los protagonistas $\mathrm{y}$ víctimas de tales acontecimientos terribles a servirse, cuando les era posible, de las distintas posibilidades formales que les ofrecían los llamados "géneros del yo" para dejar constancia de lo vivido y colaborar así a la edificación, a partir de la propia experiencia, del recuerdo colectivo. De este modo, memorias, autobiografías, diarios, entre otras manifestaciones textuales de difícil clasificación por su hibridez o singularidad, se consolidaban como los cauces más adecuados para contar la verdad, merced a lo que Lejeune denominó pacto autobiográfico, especialmente cuando esta ha sido edulcorada $\mathrm{u}$ ocultada en aras de la convivencia pacífica y sin rencores. La narrativa ficcional, por su parte, no se mantuvo ajena a este servicio "testimonial" pero es innegable que el uso de la ficción para el relato de determinadas experiencias vitales ha venido planteando, de manera más o menos intensa, problemas de naturaleza ética y moral. Baste recordar en este sentido la reapertura del debate sobre la idoneidad de la ficción cinematográfica para narrar el holocausto tras el estreno y reconocimiento internacional de El hijo de Saúl de Lázsló Nemes (2015).

Sin embargo, las particulares circunstancias históricas que vivió España después de la Guerra Civil, con un régimen silenciador del enemigo superviviente a través de una férrea censura, tuvo como consecuencia más inmediata que la ficción se convirtiera en el cauce literario menos sospechoso para dejar constancia, subrepticiamente, de la desolación que arrasó las vidas de los participantes en la contienda y de las víctimas del franquismo posterior. Así lo expresa Celia Fernández Prieto:

La imagen de la guerra había quedado fijada en un sistema de iconos y de tópicos oficiales; cualquier otro tratamiento estaba vetado. De ahí que los ecos de la guerra aparecieran desplazados, proyectados simbólicamente en los universos de la infancia o en la desolación expresionista de los espacios urbanos y de sus habitantes, y se filtrasen como un ruido sordo y perturbador bajos las estructuras narrativas, los personajes y las tensiones estilísticas de algunas de nuestras mejores novelas de los años 50 a 70. (Fernández Prieto, 2005, p. 173)

Sin haber dejado nunca de estar presente en la novela española de la segunda mitad del siglo XX, es cierto, y así ha sido insistentemente repetido, que a finales del siglo pasado y principios de este asistimos a un aumento más que significativo de narraciones que pretenden recoger la experiencia vital de los silenciados. Como cabría esperar, estas narraciones se sitúan dentro del amplio espacio de la ficción porque sus autores pertenecen a una generación que no vivió en carne propia los desastres de la contienda y los peores años del franquismo pero son descendientes o se sienten herederos de toda una generación de españoles que no tuvieron el 
derecho a la palabra escrita. Son muchas las obras, de desigual calidad y éxito, que podrían citarse para ejemplificar esto que venimos diciendo y que acuden a la mente de todos, La larga marcha (1996) de Rafael Chirbes, El lápiz del carpintero (1998) de Manuel Rivas, El nombre que ahora digo (1999) de Antonio Soler, Soldados de Salamina (2001) de Javier Cercas, La voz dormida (2002) de Dulce Chacón, Las trece rosas (2003) de Jesús Ferrero, El vano ayer (2004) de Isaac Rosa, El corazón helado (2007) de Almudena Grandes, etc. De este modo la novela asume, en palabras de Fernández Prieto, "una función moral —o, si se prefiere, terapéutica-: restaurar una memoria secuestrada, devolver la voz a quienes la habían perdido, conjurar el olvido" (2005, p. 177).

Dibujado sucintamente este panorama, la cuestión que nos interesa abordar aquí es de qué manera la ficción resulta un instrumento idóneo para la reconstrucción de la memoria histórica, puesto que aquella no está sometida al "pacto de verdad", y si su eficacia, con este fin, es parangonable a la que tradicionalmente han mostrado los textos de carácter autobiográfico, entendidos en sentido amplio.

\section{PRESUPUESTOS TEÓRICOS}

Para demostrar el importante papel que puede desempeñar la ficción en la reconstrucción de la memoria histórica hemos de explicar, en primer lugar, el efecto que esta tiene en el lector a partir de algunos conceptos propuestos por la fenomenología y sabiamente aprovechados por la pragmática literaria y la estética de la recepción, que ha permitido reconsiderar el funcionamiento de la ficción con independencia de los contenidos o temas que esta trate.

Escribía el profesor Pozuelo en su Poética de la ficción que "el dominio de lo ficcional comprende la totalidad de lo literario" (1993, p. 12). Esta afirmación parece entrar en cuestionamiento cuando nos enfrentamos a textos como el de Alberto Méndez cuyo contenido, según especifica el propio autor, "son historias verdaderas, aunque los nombres y los sitios hayan sido cambiados y la imaginación haya enriquecido los detalles. Las he escrito con el olor y el ruido de la memoria de otros" (Garzón, 2004). En esta confesión del escritor están incluidas dos palabras que van a resultar clave para nuestra reflexión, a saber, "verdadera" e "imaginación".

Para ir encauzando el tema, hemos de partir de la identificación que se instaura a partir del siglo XIX, probablemente como consecuencia del éxito de la estética realista y su reverberación en la entronización de la novela como gran subgénero narrativo, cuya sombra se prolonga hasta nuestros días, entre dos conceptos que la tradición literaria había mantenido separados durante siglos, el concepto de realismo y el de verosimilitud. Esta contaminación, como nos muestra Pozuelo Yvancos, se debe a que "la literatura crea simulacros de realidad, representa acciones humanas y realiza un peculiar isomorfismo de manera que los hechos representados se 
asemejan a los acaecidos a personajes que se mueven realmente en el escenario de nuestra existencia" (1993, p. 18). Sin embargo, nuestra experiencia como lectores nos enseña que los hechos más fantásticos pueden resultar verosímiles y los más cercanos a la realidad absolutamente increíbles.

Traemos a colación estos conceptos porque, además de andamiaje previo que va a resultar imprescindible para recordar el funcionamiento de la ficción desde nuestra perspectiva teórica, son pertinentes para el estudio del texto que nos ocupa. Y es que entre las cualidades que, de manera reiterada, se han destacado de los relatos de Méndez están su carácter realista y, sospechosamente unido a este rasgo, el uso de materiales y testimonios verídicos. Lo que pretendemos demostrar es que estos dos aspectos, por lo demás obvios, no son per se y en exclusiva los responsables de la verosimilitud de Los girasoles ciegos y, consecuentemente, de su ensalzamiento como texto de referencia en el necesario proceso de reconstrucción de la memoria histórica española. La verosimilitud es el resultado de un proceso más complejo en el que entran en juego rasgos inmanentes y elementos extratextuales que colaboran decididamente en que los relatos proyecten ese efecto de realidad. Pero vayamos por partes.

La intensa y extensa reflexión sobre la ficción que se desarrolla en la segunda mitad del siglo XX coincide —o quizá sea consecuencia - con la reacción a los excesos estructuralistas de los años precedentes cuyo ceñimiento, cuasi obsesivo, a las cualidades inmanentes del texto había hecho olvidar otros aspectos que era necesario tener en cuenta para la compresión del hecho literario. La propuesta procedente de la pragmática que concibe la literatura no como una estructura diferenciada sino como una forma de comunicación especial otorgaba un lugar preeminente a la ficción. Sin entrar en las distintas teorías que pretendieron explicar la naturaleza de los actos de habla de los textos ficcionales por parte de los más destacados nombres de la pragmática (J. Searle, R. Ohmann, G. Genette, etc.) es preciso recordar, para sustentar nuestra reflexión, que lo que singulariza los mensajes verbales del texto literario es su carácter imaginario y, como consecuencia, los actos de habla que en este espacio tienen lugar son igualmente ficticios (Martínez Bonati, 1983). Establecida esta premisa, se concluye en que el proceso de comunicación que se desencadena en literatura y, más concretamente, en narrativa se desdobla entre aquel que se establece entre el narrador y el narratario, entidades ficcionales ampliamente estudiadas desde planteamientos inmanentes, y el que se produce entre el autor y los lectores, entidades histórico-empíricas cuya relación ha atraído el interés de la sociología de la literatura, entre otras corrientes. Pozuelo Yvancos nos recuerda al hablar sobre los actos de ficción que:

El texto no es solamente, como había subrayado el esquema semiótico de Morris, unas relaciones de los signos entre sí (Sintaxis) y de los signos con la realidad o mundo (Semántica), también es una relación entre los comunicantes — hablante y oyente — entre 
sí y con el signo. De esa relación se ocupa la pragmática. [...] El problema de la "ficción" literaria alcanza de lleno desde sus orígenes a esta pragmática o lingüística de la acción, precisamente en la medida en que el ser ficcional de la literatura propone un uso particular en que se suspenden las exigencias de verdad y de compromiso para con el mensaje de los intervinientes en el acto de comunicación. (1993, pp. 73-74)

En este sucinto recorrido teórico es posible percibir el protagonismo que, paulatinamente, va adquiriendo el receptor en la comprensión del hecho literario. Aunque este nunca ha estado completamente ausente de las reflexiones teóricas, es innegable que la atención que se le había prestado era notablemente inferior a la concedida al autor o al texto. Será la estética de la recepción, con la Escuela de Constanza como uno de sus núcleos más sólidos y reconocidos, la que contribuya determinantemente a indagar en el encuentro de la obra con su destinatario. Fue, como se sabe, la fenomenología de Husserl el precedente más remoto, probablemente, de este cambio de paradigma en la medida en que el objeto de reflexión filosófica se desplaza de "los objetos del mundo" a "los contenidos de nuestra conciencia". La indagación husserliana en la relación sujeto/objeto se sustenta sobre el denominado "método fenomenológico" que presenta dos fases, a saber, la epojé ${ }^{2}$ y la reducción. Nos interesa la primera de estas dos etapas, especialmente, porque esta ha servido para explicar de una manera plausible el funcionamiento de la ficción. Para el filósofo alemán el viejo término griego, referido a la actitud natural de creer que la realidad es algo independiente del sujeto, es un paso imprescindible para alcanzar una actitud reflexiva gracias a la cual el hombre se desliga del mundo exterior y se repliega hacia sí mismo, hacia lo que es en verdad. Del mismo modo, ante el texto literario, el lector tiene que dejar en suspenso sus cautelas racionales, "la voluntaria suspensión del descreimiento" de la que hablaba Coleridge, y aceptar la entrada en un mundo ficticio que vive transitoriamente como si fuese real. Para ello es necesario asumir la epojé que supone el pacto de ficción, como acto voluntario, para proyectar sobre el texto la propia experiencia personal —el Sujeto constituye los objetos-, de manera que percibimos como reales unos acontecimientos que son, a todas luces, ficticios. Desde el punto de vista de la fenomenología, desde la cual se viven por parte del receptor los hechos formando parte de su propia experiencia, los sucesos narrados se convierten o le son dados como fenómenos. ${ }^{3}$ Tal teoría se sustenta sobre el concepto de vivencia diltheano (Erlebnis), que asume Husserl, y que en términos literarios supone que:

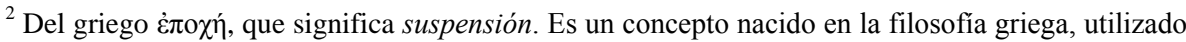
principalmente por la corriente escéptica. Originariamente, según la definición dada por Sexto Empírico significa un estado mental de "suspensión del juicio", un estado de la conciencia en el cual ni se niega ni se afirma nada. Para Husserl, la epojé consiste en la "puesta entre paréntesis" no solo de las doctrinas sobre la realidad sino también de la realidad misma.

${ }^{3}$ FENÓMENO: del griego paıvó $\mu \varepsilon v o v$, entendido, según Kant, como lo que es objeto de la experiencia sensible.
} 
La virtualidad del texto y nuestra vivencia intencional ${ }^{4}$ del mismo nos llevan a elevar cualitativamente el rango de su mundo interno referencial hasta integrarlo sin reserva alguna en el nuestro propio, externo, experiencial [...]

Ahí está la verdad de la literatura que es, como Pablo Picasso decía del arte en general, "una mentira que nos hace caer en la cuenta de la verdad". Una verdad que para ser admitida no nos exige renunciar a la consciencia de la autonomía del texto artístico, como constructo, frente a toda realidad previa y a las intenciones de su autor. Es en nosotros, sus lectores, donde al apropiárnosla como objeto estético pleno, actualizado, surge el realismo. (Villanueva, 2007, p. 211)

Este desempeño del lector como pieza clave "cocreadora" del texto literario fue extensamente estudiada, como se sabe, por H. R. Jauss en Experiencia estética $y$ hermenéutica literaria (1986) y por W. Iser en El acto de leer (1987). Será, precisamente, la teoría de este último sobre el efecto de la lectura en el receptor ${ }^{5}$ la que nos resulte especialmente valiosa para explicar la eficacia de la literatura en la recuperación de la memoria porque el texto se actualiza "sólo mediante las actividades de una conciencia que lo recibe, de manera que la obra adquiere su auténtico carácter procesal sólo en el proceso de lectura. [...] La obra de arte es la constitución del texto en la conciencia del lector" (Iser, 1989, p. 149).

En lo que el teórico alemán llama la "realización" de texto tiene lugar la labor de reconstrucción que el lector ha de llevar a cabo a partir de la obra proporcionada por el autor, que nunca es un todo cerrado y completo sino una estructura esquemática que precisa "ser completada". La compresión de la obra necesita de la activa participación del receptor que ha de rellenar los "lugares de indeterminación", utilizando el concepto de Ingarden, ${ }^{6}$ que el texto presenta con elementos de su propia experiencia. El resultado es una organización coherente que genera la ilusión, que sabemos transitoria, pero que formará parte de nuestras vivencias:

Al leer reaccionamos frente a las imágenes que nosotros mismos vamos produciendo, lo que nos posibilita experimentar el texto como una vivencia personal. A través de la representación, que nos permite una escenificación de la realidad, ésta puede entrar en la conciencia del lector, al igual que también sucede en el sueño. (Hermosilla, 2008, p. 252)

\footnotetext{
${ }^{4}$ La fenomenología estudia la relación entre el fenómeno y la Conciencia respecto a la cual éste aparece o se presenta portando un sentido y una validez. Para precisar en qué se cimenta esta relación Husserl acude a un concepto clave: "la intencionalidad". Esta es definida como la esencia misma de la conciencia. Puesto que la conciencia no es sino una corriente de vivencias sucede entonces que todas las vivencias de la conciencia son en su raíz "intencionales", son "vivencias de algo". Dicho de otro modo: todas las vivencias de la conciencia son vivencias de algo que se presenta en ellas, para ellas, por ellas y desde ellas.

${ }^{5}$ Vale recordar que Iser desarrolla su teoría a partir de planteamientos de raíz fenomenológica (R. Ingarden) y pragmática.

${ }^{6}$ Los "lugares de indeterminación" fueron estudiados y analizados en diferentes estratos por Roman Ingarden en La obra de arte literaria, en 1931.
} 
No obstante, para que el lector actualice el texto como propia vivencia es necesario, además, que este esté dotado de una estructura formal idónea. La elección de Los girasoles ciegos para ejemplificar la eficacia de los relatos ficcionales frente a los no ficcionales en la reconstrucción de la memoria se debe, precisamente, a que reúne unos requisitos formales idóneos para hacer creer al lector que lo que se está narrando "fue verdad". En el origen de este planteamiento se encuentra la conocida tesis de Phillipe Hamon (1981) sobre el realismo quien, desde una perspectiva pragmática, desplaza el centro de atención del modo en que la literatura copia la realidad al modo en que la literatura nos hace creer que copia la realidad. La huella que deja en el lector esta "creencia" es más poderosa y eficaz que cualquier texto de naturaleza histórica. Veámoslo.

\section{LOS GIRASOLES CIEGOS: NADA ES REAL PERO TODO VERDADERO}

Nos recuerda Iser en "La realidad de la ficción" (1989, p. 165 y ss.) que si las imágenes que construimos con la lectura, en general, las interiorizamos como propias, este proceso tiene lugar con mayor fuerza cuando partimos de un discurso que propicia este fenómeno. Esto es, precisamente, lo que ocurre con un texto como el que nos ofrece Méndez en el que se hace uso de técnicas ampliamente consagradas en literatura para generar el efecto de realidad perseguido, y que a continuación se verán, al tiempo que remite a las afueras del discurso en la convicción de que cuanto mayor sea la precisión con que el universo narrativo es codificado menos margen le quedará al lector para el cuestionamiento de lo real. La presencia de nombres propios, lugares y hechos históricos y la manera en que estos elementos se imbrican en el relato como argumentos de autoridad anclan al receptor literario a una realidad que, además, le resulta próxima en términos cronológicos y, en muchos casos, sentimentales.

El narrador heterodiegético de la primera derrota comienza su relato con un adverbio temporal que sitúa la voz enunciadora del discurso y a sus narratarios a una imprecisa distancia cronológica de los hechos que se van a narrar: "Ahora sabemos que el capitán Alegría eligió su propia muerte a ciegas" (p. 13). ${ }^{7}$ Ese nosotros, que recorre todo este primer texto de Los girasoles ciegos de manera insistente, ${ }^{8}$ revela el interés de un colectivo, como señala Anthony Nuckols (2011, p. 192), por conocer la historia del capitán Alegría como parte de su memoria y constituye un magnífico

\footnotetext{
${ }^{7}$ Todas las citas de Los girasoles ciegos que recogemos en este estudio están tomadas de la edición de Anagrama del año 2004, por lo que solo pondremos en el cuerpo del texto el número de página.

8 "Sabiendo ahora lo que sabemos" (p. 14); "sabemos por los comentarios" (p. 16); "Gracias a él sabemos" (p. 18); etc.
} 
ejemplo de la capacidad de la narrativa para reproducir en su discurso un proceso comunicativo semejante al que se da fuera de él entre autor, texto y lector real.

Méndez opta, en esta primera derrota, por un formato discursivo cercano al reportaje periodístico sustentado sobre los testimonios de los que conocieron al singular "rendido", los documentos registrados por los guardias de las diferentes prisiones por las que pasó, el acta del juicio en el que fue condenado a muerte acusado de traición militar en tiempos de guerra, cartas y notas manuscritas por Alegría. Todo ello acertadamente compuesto para imprimir en el relato lo que Mechthild Albert (2006, p. 22) considera un valor documental-informativo que sugiera autenticidad y opere en el sentido de simulacro de verdad:

Éste es el documento más real que tenemos de lo realmente ocurrido, la única verdad que refrenda nuestra historia, que, probablemente, tuvo bastante semejanza con la que estamos contando. De no haber temido que nuestra narración se malinterpretara, nos habríamos limitado a transcribir el acta del juicio donde se condenó a Carlos Alegría a morir fusilado por traidor y criminal de lesa patria. (p. 26)

La insistencia en la veracidad de lo que se está contando es motivo de preocupación para este narrador desconocido que se oculta tras la martilleante primera persona del plural. Sin embargo, como puede deducirse de las palabras que acabamos de citar, el "cronista" es consciente de que el simple manejo de fuentes documentales fidedignas no construyen, por sí mismas, la verdad de lo vivido: "Los documentos que fueron generando los guardianes del laberinto y las pocas cartas que escribió son los únicos hechos ciertos, lo demás es la verdad" (pp. 24-25). Se hace necesaria, como recuerda Maldonado Araque (2009, p. 75), la ficción literaria para que lo narrado no se malinterprete en términos históricos. La primera derrota emerge, de este modo, como ficción autoconsciente de su eficacia para la preservación de la memoria en la medida en que los receptores se constituyen en testigos discursivos de los acontecimientos relatados ya que no es hasta "ahora que sabemos", tantas veces repetido, ahora que leemos y reconstruimos mentalmente lo contado, que la historia del capitán Alegría existe.

El segundo capítulo se construye sobre el conocido recurso del manuscrito encontrado cuyo cultivo, según señala Rivas Hernández (2002, pp. 156-157), ha sido especialmente significativo en la narrativa realista en aras de persuadir al receptor literario de la veracidad de lo narrado. Parece coherente que Méndez se valga de esta técnica pues recordemos que sus cuatro historias están sustentadas sobre el fingimiento de relatar acontecimientos realmente ocurridos. Como es habitual en este tipo de texto, coexisten dos voces narradoras que se sitúan en distinto plano desde el punto de vista ficcional, es decir, tenemos una ficción dentro de otra: la historia marco está protagonizada por un personaje, el editor, que encuentra un cuaderno manuscrito de veintiséis páginas en el Archivo General de la Guardia Civil 
y la segunda historia, la principal, es la que resulta de la transcripción de ese cuaderno donde un joven poeta deja atestiguados los últimos días de su existencia.

No vamos a detenernos en la conmovedora historia del supuesto Eulalio Ceballos Suárez, "algo truculenta quizá aunque magistralmente narrada" (Mainer, 2006, p. 157), sino en los recursos que Méndez emplea para dotar de verosimilitud a su relato y en la intervención del editor en la recepción que tenemos del mismo en la medida en que él es su "primer lector":

Este texto fue encontrado en 1940 en una braña de los altos de Somiedo, donde se enfrentan Asturias y León. Se encontraron un esqueleto adulto y el cuerpo desnudo de un niño de pecho sorprendentemente conservado sobre unos sacos de arpillera tendidos en un jergón; una piel de lobo y lana de cabra montesa, pelos de jabalí y unos helechos secos les cobijaban. (p. 39)

Desde la primera página se nos informa de que el texto que leeremos a continuación es el resultado de un hallazgo casual, — "buscando otros documentos [...] encontré un sobre amarillo" (p. 39) - que llama la atención del editor por razones estrictamente literarias: el cuaderno de hule manuscrito que guardaba el sobre citado se halló en una cueva, con dos cadáveres, en cuya pared figuraba escrito "infame turba de nocturnas aves". El intertexto gongorino se utiliza como activador de la curiosidad del personaje cuya voz abre y cierra la segunda derrota y lo reviste de las funciones de un receptor literario en tanto el contenido del cuaderno manuscrito, con forma de diario, no se ofrece al lector de manera aséptica y desnuda sino que su transcripción está salpicada de intervenciones de este editor que se afana en dar el mayor número de datos posibles para completar la adecuada lectura del manuscrito encontrado y que no permite, al lector real, olvidar el artificio literario sobre el que se edifica esta historia. Además, estas intervenciones no son, como cabría esperar en un transcriptor, meramente descriptivas sino que, a medida que avanza las páginas del cuaderno, empiezan a introducir consideraciones interpretativas ${ }^{9}$ que alcanzan su máxima expresión en las palabras que cierran este segundo capítulo:

(NOTA DEL EDITOR: El año 1954 fui a una aldea de la provincia de Santander llamada Caviedes. Efectivamente está colgada de la montaña y huele al mar próximo aunque desde él no puede divisarse porque se asoma hacia el interior de un valle. Pregunté aquí y allá [...] Si fue él el autor de este cuaderno, lo escribió cuando tenía dieciocho años y creo que ésa no es edad para tanto sufrimiento.) (p. 57)

\footnotetext{
${ }^{9}$ (Aquí se produce un significativo cambio de caligrafía. Aunque la pulcritud de la escritura se mantiene, los trazos son algo más apresurados. O, cuando menos, más indecisos. Probablemente ha transcurrido bastante tiempo. [...] Probablemente la mano del niño le sirvió de plantilla. [...] hay un dibujo donde se ve la figura de un lobo con un niño a la grupa; el aspecto de ambos es risueño y levitan sobre un campo florido, como si volaran) (pp. 48-50).
} 
En la "Segunda derrota" no solo encontramos magníficamente representado ese rasgo que caracteriza la narrativa de reproducir en su interior el mismo proceso comunicativo que la genera sino que, además, muestra, dentro del universo de ficción que plantea, la importancia del receptor en la "existencia" del texto literario y, más aún, la huella que el texto deja en el lector que hace suyo lo leído porque esta experiencia lo transforma: el editor que publica el cuaderno en 1954 no es el mismo que el que lo descubrió casualmente en 1952.

En "El idioma de los muertos" Méndez recupera el relato heterodiegético y con focalización cero para abordar la historia de Juan Senra. Frente a los dos capítulos precedentes, en este caso no tenemos un narrador que participe, de una u otra forma, en la trama que su discurso construye: no sabemos quién es y no revela sus fuentes, ni tan siquiera la de las cartas que el recluso escribe a su hermano desde la cárcel y que se incorporan al relato en letra cursiva. Se trata, en definitiva, de un narrador decimonónico revestido de la autoridad que la estética realista concede a esta voz enunciadora que sustenta la verosimilitud del texto en tanto que este está configurado para propiciar una lectura que actualiza el texto de manera realista. Entre los recursos que son seleccionados para hacer efectiva esta impresión de realidad destaca la utilización de un personaje histórico, el coronel Eymar que, como se sabe, ejerció de juez en el juzgado Militar Especial para los Delitos de Espionaje, Masonería y Comunismo durante los primeros años de la dictadura franquista. En esta ocasión Méndez, como nos recuerda Bueno Maqueda (2006, p. 174), opta por situar a esta figura anclada a la realidad en un segundo plano en la trama narrativa y caracterizarlo de manera desmitificada "para que el discurso referencial del que pudiera partir el lector le lleve a un principio de descreimiento".

Algunos de los trabajos que han abordado el estudio de esta tercera derrota insisten en que en ella se da una bien construida contraposición entre la ficción que Senra cuenta para salvar su vida y la verdad que conocemos a través del relato que el narrador omnisciente hace de los pensamientos del recluso. Sin embargo, no parece demasiado preciso hablar de ficción para definir la historia del preso sobre las razones del encarcelamiento y muerte del hijo del coronel Eymar. Juan Senra no elabora una ficción sino "una mentira prolongada y densa" (p. 75) y por este motivo es posible contraponerla a la verdad que oculta hasta el final. No tenemos, en este caso, una estructura similar a la que nos presentaba el autor en la segunda derrota, es decir, no se propone, en ningún caso, una ficción dentro de otra, sino una mentira dentro de la ficción:

Juan le dijo que había recordado la verdad, [...] Todo lo que les he contado hasta ahora es mentira. Lo hice para salvarme $[\ldots]$

Todo fue como un fulgor, una sacudida que congeló el aliento del coronel Eymar y de su esposa. Escucharon aquel fugaz retrato de su hijo trazado con unos colores que identificaron inmediatamente con los colores de la verdad. Nadie miente para morir. (p. 100) 
"El idioma de los muertos" nos ofrece un excelente ejemplo para comprender que ficción y mentira no son, en ningún caso, conceptos sinónimos ni identificables. No debe olvidarse que el primero es una construcción que se propone como verdadera y se vive transitoriamente, por parte del receptor, como real siendo consciente al mismo tiempo de su carácter imaginario mientras que el segundo es una "expresión o manifestación contraria a lo que se sabe, se piensa o se siente", según figura en la última edición del $D R A E$, que es exactamente lo que hace Juan Senra. Las consecuencias y efectos de ambas se revelan, como cabría esperar, bien diferentes.

La cuarta derrota, que da título al volumen, se construye sobre la alternancia de tres voces narrativas, dos homodiegéticas, correspondientes al hermano Salvador (en cursiva) y al Lorenzo adulto (en negrita), y una heterodiegética, procedente de una instancia enunciadora ajena a la historia cuya función es completar parte de los vacíos de información que, por razones obvias, presentan los respectivos discursos de los dos protagonistas que cuentan. El resultado, como señala Matos-Marín (2015, p. 218), es una estructura textual más compleja que las anteriores donde el lector tiene que recomponer, a partir de la información proporcionada por cada parte, lo ocurrido a los miembros de una familia que intentan ocultar la supervivencia del padre, escondido en un armario de la casa, que oficialmente está muerto.

La alternancia de puntos de vista que lleva aparejada, en este caso, el uso de varias voces narrativas contribuye a plantear una interesante reflexión sobre los límites de la representación de la realidad, de reconstruir lo acontecido porque nuestro conocimiento es, siempre, parcial: "Probablemente los hechos ocurrieron como otros los cuentan" (p. 106). Ni siquiera el discurso del narrador omnisciente nos permite aceptar su relato como reelaboración objetiva de los hechos porque este se ve contaminado, en ocasiones, de la perspectiva de alguno de los personajes víctima que protagoniza la cuarta derrota:

Hablar siempre en voz baja es algo que, poco a poco, disuelve las palabras y reduce las conversaciones a un intercambio de gestos y miradas. El miedo, como la voz queda, desdibuja los sonidos porque el lado oscuro de las cosas sólo puede expresarse con silencio. (p. 115)

Considera atinadamente Catherine Orsini-Saillet (2006, p. 11) que la reconstrucción de la historia que hace el diácono, por su forma epistolar, y el Lorenzo adulto, por su diseño memorialístico, dan una ilusión de veracidad. Pero a ello también contribuyen, de manera decisiva, las intervenciones del narrador heterodiegético, como la recién citada, en las que este ejerce lo que Genette (1989, p. 310) denominó función testimonial e ideológica. Ser un enunciador ajeno a la historia no le impide manifestar los sentimientos que en él despiertan determinados episodios o introducir un comentario autorizado de la acción que está narrando. La ficción propuesta, pues, se vale de unos recursos compositivos que, sabiamente orquestados, 
contribuyen a dar una fuerte sensación de realidad y a que el lector actualice de manera realista el texto. Este cuarto relato, además, dota al conjunto de una estructura unitaria desde el punto de vista sintáctico y semántico: sintáctico porque el discurso del diácono, que se expresa en primera persona, se contrapone a las voces del bando perdedor, transmitidas directa o indirectamente; y semántico porque el hermano Salvador, frente a Ricardo Mazo y, también, frente a Carlos Alegría, Eulalio Ceballos o Juan Senra que optan por el "suicidio" dignificante, decide arrastrar una miserable existencia:

Aquí termina mi confesión, Padre. No volveré al convento y trataré de vivir cristianamente fuera del sacerdocio. Absuélvame si la misericordia del Señor se lo permite. Seré uno más en el rebaño, porque en el futuro viviré como uno más entre los girasoles ciegos. (p. 155)

Los rasgos formales que presentan las cuatros derrotas que compone Alberto Méndez, tal y como se ha analizado, están en consonancia con una clara tendencia que comparte una buena parte de las narraciones literarias que abordan el tema de la Guerra Civil española como un referente simbólico de la memoria colectiva, a saber, el de crear "figuras ficticias que recuerdan el pasado o que intentan reconstruirlo basándose en memorias y/o documentos hagiográficos" (Jünke, 2006, p. 106). Las posibilidades que la ficción ofrece para cumplir el cometido del recuerdo son extraordinarias porque, como sostiene Txetu Aguado:

La relación literaria es de empatía con quien no tiene voz, con el desaparecido o con el largo tiempo muerto; es un acercarnos desde la ficción a lo que de otra manera nos sería inaccesible [...] recuperando simbólicamente un diálogo con el pasado de otro modo imposible. (2011, p. 47)

Esto es viable no solo porque el texto posea unas características inmanentes que reproduzcan lo acontecido sino porque la ficción ejerce sobre el lector un poderoso efecto que es consecuencia de esa "voluntaria suspensión del descreimiento" por el que vivimos como real unos acontecimientos, que por muchos datos históricos que contengan, son imaginarios. Además, la realización del texto tiene lugar, como nos mostraba Iser, en la conciencia del lector que utiliza elementos tomados de su propia experiencia para completar la estructura esquemática que es la obra. En este proceso, donde dejamos de ver las letras de las páginas y a través de la activación de imágenes mentales va tomando cuerpo un "mundo posible" (Albadalejo, 1986), se genera la ilusión de realidad, $\mathrm{y}$, al final, lo leído formará parte de nuestras vivencias. Obviamente, este fenómeno acontece con mayor fuerza cuando partimos de un discurso con unas características que propician este proceso como es el caso de Los girasoles ciegos.

La memoria colectiva no solo se construye con materiales históricos o testimonios reales, con documentos autógrafos o experiencias transmitidas oralmente, 
sino con relatos ficcionales que han de ser, ineludiblemente, considerados en este sentido. No, como se ha visto, porque intenten reproducir una realidad inasible sino porque "hacen vivir" al receptor lo narrado como propio y la huella dejada es imborrable. Indiscutiblemente el conocimiento que proporciona no es de carácter histórico, en sentido estricto, sino lo que Rosa Regás llamó el "conocimiento poético" (2004, p. 71). Así, la única obra de Alberto Méndez constituye un excelente ejemplo de la capacidad que puede tener la novela como mecanismo activador de la memoria: nada en Los girasoles ciegos es real pero todo verdadero. 


\section{BIBLIOGRAFÍA}

Aguado, T. (2011). "Modelos emocionales de memoria: el pasado y la transición". En T. Dorca \& P. Álvarez-Blanco (Coords.), Contornos de la narrativa española actual (2000-2010) (pp. 45-53). Madrid: Iberoamericana-Veuvert.

Albadalejo, T. (1986). Teoría de los mundos posibles y macroestructura narrativa. Alicante: Universidad de Alicante.

Albert, M. (2006). "Oralidad y memoria en la novela memorialística". En U. Winter (Ed.), Lugares de memoria de la Guerra Civil y el Franquismo (pp. 21-38). Madrid: Iberoamericana-Veuvert.

Bueno Maqueda, F. T. (2006). "La ficción de la literatura o la verdad de la guerra: apuntes, retos y contradicciones en Los girasoles ciegos". En Guerra y literatura: III Simposio Internacional sobre Narrativa Hispánica Contemporánea, Puerto de Santa María, 9, 10 y 11 de Noviembre de 2005 (pp. 167-185). Puerto de Santa María: Fundación Luis Goytisolo.

Fernández Prieto, C. (2005). "Representaciones de la guerra civil española en la novela y en el cine desde la década de los 90". En P. Poyato (Comp.), Historias, motivos y formas del cine español (pp. 173-187). Córdoba: Plurabelle.

Garzón, R. (2004, 20 febrero). "Alberto Méndez recupera la posguerra en Los girasoles ciegos". El País. Recogido en: http://elpais.com/diario/2004/02/20/cultura/1077231604_850215.html

Genette, G. (1989 [1972]). Figuras III. Barcelona: Lumen.

Hamon, P. (1981). Introduction à l'analyse du descriptif. París: Hachette.

Hermosilla Álvarez, M. A. (2008). "El realismo intencional de El casamiento engañoso y El coloquio de los perros". En J. Jiménez Heffernan (Ed.), La tropelía. Hacia el coloquio de los perros (pp. 225-266). Madrid: Artemisa.

Iser, W. (1987 [1976]). El acto de leer: teoría del efecto estético. Madrid: Taurus.

— (1989 [1979]). "El proceso de lectura" y "La realidad de la ficción". En R. Warning (Ed.), Estética de la recepción (pp. 149-164 y 165-196). Madrid: Taurus.

Jauss, H. R. (1986 [1977]). Experiencia estética y hermenéutica literaria: ensayos en el campo de la experiencia estética. Madrid: Taurus.

Jünke, C. (2006). "«Pasarán los años y olvidaremos todo»: La Guerra Civil española como lugar de memoria en la novela y el cine actuales en España”. En U. Winter (Ed.), Lugares de memoria de la Guerra Civil y el Franquismo (pp. 101-129). Madrid: Iberoamericana-Veuvert.

Mainer, J. C. (2006). Para un mapa de lecturas de la Guerra Civil (1960-2000). En S. Juliá (Dir.), Memoria de la guerra y del franquismo (pp. 135-161). Madrid: Taurus.

Maldonado Araque, F. J. (2009). "La «primera derrota» de Los girasoles ciegos (Guerra, Vida y Libertad en el Capitán Alegría)". Voz y Letra: Revista de Literatura, 20-1, 73-90.

Martínez Bonati, F. (1983). La estructura de la obra literaria. Barcelona: Ariel.

Matos-Martín, E. (2015). "Homo sacer y franquismo. Una lectura crítica de Los girasoles ciegos de Alberto Méndez". Anales de literatura española contemporánea, 40, Número Extra 1, 207-232.

Méndez, A. (2004). Los girasoles ciegos. Barcelona: Anagrama.

Nuckols, A. (2011). "La novela contemporánea como instrumento de duelo. Los girasoles ciegos de Alberto Méndez". Revista internacional de estudios vascos, 8, 180-199.

Orsini-Saillet, C. (2006). "La memoria colectiva de la derrota: Los girasoles ciegos de Alberto Méndez". En Congreso de la Guerra Civil Española 1936-1939 (pp. 1-16). Sociedad Estatal de Conmemoraciones Culturales. Recogido en: https://www.researchgate.net/publication/28210955_La_memo ria_colectiva_de_la_derrota_Los_girasoles_ciegos_de_Alberto_Mendez.

Pozuelo Yvancos, J. M. (1993). Poética de la ficción. Madrid: Síntesis.

Regás, R. (2004). "El pozo del miedo". En E. Silva, P. Salvador, M. S. A. Esteban Recio \& J. Castán (Coords.), La memoria de los olvidados: un debate sobre el silencio de la represión franquista (pp. 69-74). Madrid: Ámbito Ediciones. 
Rivas Hernández, A. (2002). "El manuscrito encontrado como recurso del realismo literario". Moenia, 8, $155-165$.

Serna, J. (2005, 3 diciembre). "La derrota sin consuelo" [Reseña de Los girasoles ciegos de Alberto Méndez]. Ojos de papel. Revista digital. Recogido en: http://www.ojosdepapel.com/Index.aspx? article $=2316$

Soler Sasera, E. (2006). "Las voces antiguas: la Guerra Civil española en algunas memorias y autobiografías del exilio literario de 1939". Olivar: Revista de Literatura y Cultura Españolas, 8 , 249-261.

Traverso, E. (2006). Els usos del passat: Història, memòria, politica (trad. G. Muñoz). Assaig, 16. Valencia: Universitat de València.

Villanueva, D. (2007). "El realismo intencional: de Pereda a Cunqueiro". En W. Matzat (Ed.), Espacios y discursos en la novela española del realismo a la actualidad (pp. 203-217). Madrid: Iberoamericana-Veuvert. 